University of Nebraska - Lincoln

DigitalCommons@University of Nebraska - Lincoln

Registration of NE Trailblazer C-1, NE Trailblazer C0, NE Trailblazer C2, NE Trailblazer C3, NE Trailblazer C4, and NE Trailblazer C5 Switchgrass Germplasms

\author{
Kenneth P. Vogel \\ University of Nebraska-Lincoln, kvogel1@unl.edu \\ Robert B. Mitchell \\ USDA-ARS, rob.mitchell@ars.usda.gov \\ Gautam Sarath \\ USDA-ARS, Gautam.sarath@ars.usda.gov
}

Follow this and additional works at: https://digitalcommons.unl.edu/usdaarsfacpub

Vogel, Kenneth P.; Mitchell, Robert B.; and Sarath, Gautam, "Registration of NE Trailblazer C-1, NE Trailblazer C0, NE Trailblazer C2, NE Trailblazer C3, NE Trailblazer C4, and NE Trailblazer C5 Switchgrass Germplasms" (2016). Publications from USDA-ARS / UNL Faculty. 1968.

https://digitalcommons.unl.edu/usdaarsfacpub/1968

This Article is brought to you for free and open access by the U.S. Department of Agriculture: Agricultural Research Service, Lincoln, Nebraska at DigitalCommons@University of Nebraska - Lincoln. It has been accepted for inclusion in Publications from USDA-ARS / UNL Faculty by an authorized administrator of DigitalCommons@University of Nebraska - Lincoln. 


\title{
Registration of NE Trailblazer C-1, NE Trailblazer C0, NE Trailblazer C2, NE Trailblazer C3, NE Trailblazer C4, and NE Trailblazer C5 Switchgrass Germplasms
}

\author{
Kenneth P. Vogel, ${ }^{*}$ Robert B. Mitchell, and Gautam Sarath
}

\begin{abstract}
NE Trailblazer C-1 (GP-101, PI 672015), NE Trailblazer C0 (GP-100, PI 672014), NE Trailblazer C2 (GP-102, PI 672016), NE Trailblazer C3 (GP-103, PI 672017), NE Trailblazer C4 (GP-104, PI 672018), and NE Trailblazer C5 (GP-105, PI 672019) switchgrass (Panicum virgatum L.) germplasms were released by the USDA-ARS and the University of Nebraska-Lincoln on 10 Sept. 2014. These germplasms were developed by six generations of divergent breeding for in vitro dry matter digestibility (IVDMD). As a result of the multigenerations of recurrent breeding, the resulting populations differ significantly for IVDMD and for 25 other forage quality or biomass composition traits, including both acid detergent and Klason lignin. Plants in the high IVDMD populations also had altered anatomical structure. The lignin concentration of the stems was altered more than that of the leaves. The germplasm populations also differ significantly for winter survival. Altering plant composition by selection for IVDMD adversely affected the winter survival fitness of the resulting populations by unknown mechanisms. Plants from these germplasms can be used in genetics studies for determining the inheritance of multiple biomass composition traits and for identifying genes controlling specific biomass composition properties and winter survival of switchgrass and other perennial grasses.
\end{abstract}

Copyright $\odot$ Crop Science Society of America. All rights reserved

Journal of Plant Registrations 10:159-165 (2016).

doi:10.3198/jpr2015.11.0070 crg

Received 22 Nov 2015. Accepted 19 Feb 2016.

Registration by CSSA.

5585 Guilford Rd., Madison, WI 53711 USA

*Corresponding author (vogelkp61@neb.rr.com)
$\mathrm{N}$ E Trailblazer C-1 (GP-101, PI 672015), NE Trailblazer C0 (GP-100, PI 672014), NE Trailblazer C2 (GP-102, PI 672016), NE Trailblazer C3 (GP103, PI 672017), NE Trailblazer C4 (GP-104, PI 672018), and NE Trailblazer C5 (GP-105, PI 672019) are upland, octaploid switchgrass (Panicum virgatum L.) populations that were developed by the USDA-ARS and the Agricultural Research Division, Institute of Agriculture and Natural Resources, University of Nebraska-Lincoln for increased (high) or decreased (low) in vitro dry matter digestibility (IVDMD) in six generations of divergent breeding using population improvement breeding procedures. The six breeding generations and associated evaluation research that resulted in the development of these germplasms were initiated in 1973 and continued for over four decades. During their development, the populations were given the name of the base population, EYxFF, followed by the breeding cycle number. The cultivar Trailblazer was developed in the first generation or cycle (EYxFF C1) of recurrent breeding for high IVDMD (Vogel et al., 1991). The resulting germplasms were renamed NE Trailblazer followed by the selection cycle in which the population was developed to simplify their nomenclature. During their development and testing, these germplasms were used in a series of previously published studies (Vogel et al., 1981, 1984, 2002, 2013; Anderson et al., 1988; Ward et al., 1989; Gabrielsen et al., 1990; Hopkins et al., 1993; Casler et al., 2002; Sarath et al., 2008, 2011) on the effectiveness of breeding for improved forage quality by selection for IVDMD in a sexual C4 perennial grass, the effect of improvements in IVDMD on animal performance, and the effect of breeding for IVDMD on biomass yield and composition and on winter survival. The resulting populations differ significantly for IVDMD and for 25 other forage quality or biomass composition traits, including both acid detergent and Klason lignin (Vogel et al., 2013) and plant anatomical structure and potential ethanol yield in a biorefinery (Sarath et al., 2008, 2011). There are also differences among the populations for winter survival. This report summarizes the development of these germplasms, the effects this breeding work had on plant fitness, physiology (winter survival),

USDA-ARS, Grain, Forage, and Bioenergy Research Unit, 251 Filley Hall, Dep. of Agronomy and Horticulture, Univ. of Nebraska-Lincoln, Lincoln, NE 68583-0937.

Abbreviations: ADF, acid detergent fiber; ADL, acid detergent lignin; BWFS, Between and Within Family; FA, ferulic acid; IVDMD, in vitro dry matter digestibility; NDF, neutral detergent fiber; NIRS, near infrared spectroscopy; PCA, p-coumaric acid. 
anatomy, biomass composition, and animal performance when grazed and the associated economic value of the improvements in forage digestibility and the potential future uses of these germplasms in research.

\section{Materials and Methods}

\section{Breeding History}

In the first three breeding generations or cycles, a modified form of Recurrent Restricted Phenotypic Selection (RRPS) was used (Vogel and Pedersen, 1993). In the first cycle, divergent selection was made for both increased IVDMD (C1) and decreased IVDMD (C-1). Plants were selected from two breeding populations, "EY" and "FF," which were similar in maturity. These populations were developed from central Great Plains switchgrass germplasm collections by pioneer switchgrass breeder L.C. Newell in the cooperative USDA-ARS and University of Nebraska grass breeding project at Lincoln, NE (Vogel et al., 1981, 1991). Plants were selected from both populations and were polycrossed in separate, isolated EYxFF Low IVDMD (NE Trailblazer C-1) and EYxFF High IVDMD C1 (Trailblazer) polycross nurseries, each containing 25 clonally replicated genotypes. The NE Trailblazer $\mathrm{C} 0$ population was synthesized by intermating 150 plants from each base population and then advancing it to the Syn 2 generation. In the subsequent two RRPS generations, selection was only for increased IVDMD. The space-transplanted selection nurseries were stratified into selection blocks. Based on visual assessment for vigor, forage yield, and other desirable traits, approximately $25 \%$ of the plants were identified for forage harvest and sampling for IVDMD. The number of plants in the selection nurseries for each RRPS breeding cycle ranged from 874 to 1200 , the number of plants sampled for forage quality ranged from 20 to $33 \%$ of the plants in the nursery, and the number of plants selected for polycrossing ranged from 51 to 87 or a selection intensity of 5 to $7 \%$ of the plants in the nurseries or 25 to $31 \%$ of the harvested and sampled plants (Vogel et al., 2013). Following the third breeding cycle, the selection method and selection criteria were changed because of major winter killing that occurred in the C4 RRPS selection nursery in the winter of 1986-1987. These plants had been established in spring 1986 and had flowered before a killing frost. Few plants in the nursery survived that winter. The switchgrass plants in the original C3 polycross nursery that did survive the winter of 1986-1987 and half-sib family seed from the polycross nursery were used to establish a Between and Within Family (BWFS) C4 selection nursery. The BWFS breeding procedure (Vogel and Pedersen, 1993) was used for breeding cycles 4 and 5 .

In the BWFS breeding cycles, replicated half-sib family plots of 7 (C4) or 10 (C5) spaced plants were established and maintained in the field for $5 \mathrm{yr}$ before final selections were made for IVDMD and winter survival on a family and within family basis (Vogel et al., 2013). The family plots were harvested for biomass yield each postestablishment year after heading to monitor biomass yields. Samples for IVDMD analyses were collected before biomass harvest for IVDMD analyses on a plot basis and on an individual plant basis the final year after best families had been selected. In the BWFS breeding cycles, selection was made for both IVDMD and winter survival on both a family and an individual plant basis because of winter survival problems exhibited by NE Trailblazer C3 in both space-transplanted and sward evaluation trials.

\section{Selection, Polycross, and Space-Planted Evaluation Nurseries}

Selection, polycross, and seed increase nurseries used in the development of these populations were located on the University of Nebraska's Agricultural Research and Development Center located between Mead $\left(41^{\circ} 09^{\prime} \mathrm{N}, 96^{\circ} 25^{\prime} \mathrm{W}\right)$ and Ithaca, $\mathrm{NE}$, and is about $50 \mathrm{~km}$ west of Omaha, NE. The Agricultural Research and Development Center will be referred to as the Mead site in this paper. In the space-transplanted selection and polycross nurseries, rows and plants within rows were spaced on 1.1-m centers, and the following cultural practices were used. Space-transplanted nurseries were established by transplanting greenhouse-grown seedlings into the selection nurseries. In the spring of each year, the nurseries were cultivated between plants and rows with $0.6-\mathrm{m}$-wide roto-tillers creating $0.2-\mathrm{m}^{2} \mathrm{mini}-$ plots for individual plants. Nurseries were fertilized annually with $112 \mathrm{~kg} \mathrm{ha}^{-1} \mathrm{~N}$, and herbicides and hand weeding were used for weed control. Space-transplanted nurseries were mowed or burned each spring to remove the accumulated biomass from the previous year.

In the BWFS selection nurseries, tillers were sampled from all plants in a family plot and bulked before harvest in the two years families were harvested on a plot basis. In the final evaluation year, the families with the greatest winter survival and IVDMD were harvested on an individual plant basis. In the C4 and C5 selection nurseries, all plants in the nurseries were scored for winter survival as the percentage of the crown from the previous winter that produced new tillers in the spring. In all selection and sward evaluation nurseries, plants or plots were harvested for biomass yield with a flail type plot harvester with a cutting height of $10 \mathrm{~cm}$. The agronomic practices for the BWFS nurseries were the same as used for the RRPS selection nurseries. Forage samples for dry matter determination and quality analyses were collected by hand harvesting tillers from plants or plots before harvest for biomass yield. The forage or biomass samples from the selection nurseries consisted of approximately 250 to $400 \mathrm{~g}$ of freshly harvested forage, which was weighed in the field, dried in a forced air oven at $50^{\circ} \mathrm{C}$ for $48 \mathrm{~h}$ and reweighed to determine dry matter concentration. The dry samples were then analyzed for IVDMD and other forage quality traits as described below in "Laboratory Analyses."

In addition to the space-transplanted selection nurseries, spaced-transplanted evaluation nurseries were used to evaluate winter survival of the $\mathrm{C}-1$ through $\mathrm{C} 3$ populations at Mead, NE, Ames, IA, and Arlington, WI (Casler et al., 2002). The management practices for these nurseries were similar to those for the selection nurseries. In addition to serving as selection nurseries, the $\mathrm{C} 4$ and $\mathrm{C} 5$ nurseries were also used to monitor survival and the effect the multiple generations of breeding had on plant composition by including the previous breeding populations in the trials along with the half-sib families (Vogel et al., 2002, 2013). An additional space-transplanted nursery was established in 2002 at Mead with replicated $(r=4)$ space-transplanted plots of 50 plants each from the $\mathrm{C}-1$ through $\mathrm{C} 4$ populations, which 
was used to identify individual plants within these populations that differed significantly for IVDMD and lignin. Ten tillers were sampled from each plant in late autumn of 2002 when the plants were at anthesis and hand separated into stem, leaf, and sheath components. These plant part components were analyzed for IVDMD, neutral detergent fiber (NDF), acid detergent fiber (ADF), and acid detergent lignin (ADL) using the same procedures described below for whole plant sample analyses. Individual plants in the populations that differed for biomass composition were used in detailed anatomical and composition research (Sarath et al., 2008, 2011).

Polycross nurseries were established by digging ramets (clonal pieces) of selected plants and transplanting them into isolated polycross nurseries. Two ramets of each selected plant were transplanted in a completely randomized design in the polycross nurseries, for which plant spacing and cultural practices were the same as used in the selection nurseries. Seed was harvested from individual plants in the polycross nurseries and threshed with a small-plot thresher. Depending on the breeding method used in the subsequent breeding cycle, the seed harvested in the first year of seed production was bulked by genotype to produce half sib family seed lots or an equal amount of seed was bulked from each plant to produce a population bulk seed lot. In subsequent years of seed production, the entire polycross nursery was harvested with a plot combine and the bulk seed was used for yield tests and seed increases.

\section{Sward and Pasture Trials}

Sward trials were seeded with small-plot drills at test locations near Mead, NE, Ames, IA, and West Lafayette, IN, into clean, firm, conventional seedbeds (Vogel et al., 1981; Hopkins et al., 1993). Seeding rate was 430 pure live seeds $\mathrm{m}^{-2}$. Atrazine (1-chloro-3-ethylamino-5-isopropylamino-2,4,6-triazine) was applied as a pre-emergence herbicide in the yield and pasture trials. No fertilizer was applied during the establishment year. In the post-establishment years, the previous year's growth was removed by mowing or burning before the start of the growing season. Nitrogen fertilizer was applied as a single annual spring application of $112 \mathrm{~kg} \mathrm{ha}^{-1}$. Forage harvests were made at each location using plot harvesting equipment with a cutting height of $10 \mathrm{~cm}$. Subsamples were collected for dry matter determinations at the time of forage harvest. Subsamples were also collected by sampling tillers from areas within each plot. Forage from the first sward trial at Mead was used for a lamb (Ovis aries) feeding trial to measure in vivo digestibility (Vogel et al., 1984). The pasture trial was planted with field-scale equipment (Anderson et al., 1988). Seeding rate and other cultural practices for the pasture trials were the same as used in the small-plot sward trials. The experimental units in the grazing trial were 0.4 -ha pastures of each strain or cultivar that were seeded in a randomized complete block design with three replicates of each strain. Pastures were fertilized with $112 \mathrm{~kg} \mathrm{ha}^{-1} \mathrm{~N}$ in the spring of each year. The pastures were not grazed or harvested the establishment year. Grazing trials were initiated in first post-establishment year. The biomass from the previous year was removed by burning in early spring before new growth was initiated in the spring. Pastures were stocked by three yearling steers (Bos taurus) in 1982 and 1983 and by four yearlings in 1985 for approximately a 2-mo grazing period each year. In 1984, the pastures were grazed by six esophageally fistulated steers to collect samples of the forage being consumed by the beef cattle (Ward et al., 1989). The pastures were stocked by three beef yearling steers when not being grazed by the esophageally fistulated steers.

\section{Laboratory Analyses}

The dried forage subsamples used in the laboratory analyses were ground through a 2-mm screen with a Wiley Mill (Thomas-Wiley Mill Co.); then a subsample was ground through a UDY cyclone mill (UDY Corp.) with a 1-mm screen for analyses. Before 1999, a modified Tilley and Terry (1963) procedure was used to determine IVDMD. In the modified procedure, which was conducted in the University of NebraskaLincoln Agronomy Department Analytical Laboratory, $6 \mathrm{~g}$ of urea was added to every $3.5 \mathrm{~L}$ of rumen fluid, and $\mathrm{HgCl}_{2}$ and $\mathrm{Na}_{2} \mathrm{CO} 3$ were deleted after the first stage. In 1999, the USDAARS Forage Quality Laboratory at Lincoln converted to a filter bag method of determining IVDMD using the procedures described by Vogel et al. (1999). The filter bag IVDMD analyses were used to determine the IVDMD of calibration samples that were used to develop near infrared reflectance spectroscopy (NIRS) prediction equations that were used to analyze the forage samples from the multisite yield tests. All ground samples were scanned on NIRSystems Model 6500 near-infrared reflectance spectrophotometer (NIRSystems, now Foss NIRSystems Inc.). The NIRS calibration sample sets for IVDMD analyses were chosen by cluster analysis of the reflectance data using procedures described by Shenk and Westerhaus (1991). Calibration samples were analyzed in triplicate for IVDMD using the filter bag method of Vogel et al. (1999). Laboratory means were used to develop a calibration equation for IVDMD by partial least squares (Shenk and Westerhaus, 1991), which was used to predict the IVDMD concentrations of the forage samples from the yield trials. Rumen fluid for all tests was obtained from the Animal Science Department at the University of Nebraska. Calibration samples for the stem and leaf samples also were analyzed using the filter bag method of analyses. Separate NIRS calibration samples were developed for the stem and leaf samples using the procedures described previously for the whole plant samples. Filter bag methods were used to determine IVDMD, NDF, and ADF of calibration samples for the plant part analyses (Vogel et al., 1999). The ANKOM ADL procedure (ANKOM Technology -9/99) was used to determine ADL of the plant part calibration samples.

\section{Characteristics Agronomic and Botanical Descriptions}

These germplasms are octaploid, upland switchgrasses that are based on plant materials that originated in the US Central Great Plains in USDA Plant Hardiness Zone 5. Because of their genetic background, they are similar to the cultivar Trailblazer in maturity and appearance. Depending on the breeding cycle, they differ from Trailblazer in biomass composition traits and winter survival. Plants in the NE Trailblazer C-1 population have greater amounts of lignified cells with thicker cell walls in the stems as compared to plants in the NE Trailblazer C3 population (Sarath et al., 2011). Stems of plants of low lignin plants in 
the NE Trailblazer C3 population also have fewer layers in the cortical schlerenchyma (Sarath et al., 2011).

\section{Forage IVDMD, Forage Yields, and Animal Performance}

\section{Cycle 1 Divergent Selection Sward Evaluation Trial}

Seed harvested from the $\mathrm{C} 1$ and $\mathrm{C}-1$ polycross nurseries plus seed harvested from the remnant parent clones in the original selection nursery were used to plant a sward trial in spring 1978. Sufficient seed was available to plant seven replicates of all strains. The cultivar Pathfinder, which was based on an earlier generation of the FF population (Newell, 1968), was included as a check. Excellent stands were obtained, and the plots were harvested for forage yield and sampled for forage quality in 1978 and 1979. The NE Trailblazer C1 strain had significantly higher IVDMD than both NE Trailblazer C-1 and Pathfinder, but the strains did not differ in forage yield (Table 1; Vogel et al., 1981). In this study and the subsequent follow-up experiments, Trailblazer was identified as "High IVDMD PC," and NE Trailblazer C-1 was identified as "Low IVDMD PC." This was the first study that demonstrated that the IVDMD of a sexual polyploid perennial C4 grass could be improved by breeding. The strains produced by bulking seed from the open-pollinated selected genotypes in the selection nursery were intermediate to NE Trailblazer C1 and NE Trailblazer C-1 for IVDMD (Vogel et al., 1981), as expected based on theoretical predictions (Vogel and Pedersen, 1993), demonstrating that polycrossing selected genotypes resulted in more genetic gain by breeding than using open-pollinated mating systems. It was fortuitous that seven replicates were used because in subsequent evaluation trials of grass experimental stains, it was found that typically, six replicates are needed to obtain significant statistical differences for a $10 \mathrm{~g} \mathrm{~kg}^{-1}$ difference in IVDMD at $P \leq 0.05$.

A lamb feeding trial was then conducted to determine if there were differences in in vivo digestibility using the forage bulked from all seven replicates of Trailblazer, NE Trailblazer C-1, and Pathfinder (Vogel et al., 1984). The high and low IVDMD strains ranked in the order expected, but the differences were not statistically different (Table 1). The limited amount of hay available restricted the number of sheep used in the in vivo test, as well as the time period of the test. These constraints restricted the statistical power of the in vivo test. As part of this study, the NDF, ADF, ADL, and crude protein concentration of the strains was also determined for the 3-yr period, 1978 to 1980. Although there were significant differences among the strains for IVDMD each year, there were no statistical differences among the strains for NDF, ADF, ADL, and crude protein concentration at this stage in the breeding program (Vogel et al., 1984).

\section{Cycle 1 Divergent Selection Pasture Evaluation Trial}

Seed of the NE Trailblazer C-1 and Trailblazer (High IVDMD PC) strains was increased in isolated increase nurseries using seed harvested from the original polycross nurseries and was used to plant replicated pastures in 1981. The four replicates of each 0.4-ha pasture were grazed by yearling steers in 1982, 1983, and 1985 (Anderson et al., 1988). There were significant differences among the strains, with the High IVDMD PC strain (Trailblazer) having significantly greater beef yearling gains per hectare and average daily gains than the other two strains. Trailblazer was released as a cultivar based on the results of this grazing study (Vogel et al., 1991). The pastures were sampled weekly during the grazing trials. The available forage (all forage above $2.5 \mathrm{~cm}$ ) was sampled weekly in each pasture; samples were also taken from the top third of the plants since the animals were preferentially grazing the tops of the canopy in the pastures. Over the $3 \mathrm{yr}$ of the grazing trial, the IVDMD of both the available forage and the canopy tops in the pastures ranked in the same order as in the small-plot sward trials (Anderson et al., 1988). The canopy tips were always greater in IVDMD than was the available forage. Although significant differences for IVDMD were found among the strains, there were no statistical differences among the strains for NDF, ADF, permanganate lignin, crude protein concentration, or mean available forage over the 3 yr of the grazing trial (Anderson et al., 1988). The pastures were used for a study with esophageal fistulated steers in 1984 to determine if the differences in beef cattle gains were due

Table 1. NE Trailblazer switchgrass germplasms mean forage in vitro dry matter digestibility (IVDMD), forage yields in sward trials, and animal performance in feeding and pasture trials after one cycle of divergent breeding for IVDMD.

\begin{tabular}{|c|c|c|c|c|c|c|c|c|}
\hline \multirow{3}{*}{ Germplasm } & \multicolumn{3}{|c|}{ Sward plots } & \multicolumn{5}{|c|}{ Pasture trial } \\
\hline & \multicolumn{2}{|c|}{ 1978-1979 meanst } & \multirow{2}{*}{$\begin{array}{c}\begin{array}{c}\text { Lamb feeding } \\
\text { trial‡ }\end{array} \\
\text { in vivo } \\
\text { digestibility }\end{array}$} & \multicolumn{2}{|c|}{$\begin{array}{c}\text { Beef yearling gains } \\
1982,1983,1985 \text { means } \S\end{array}$} & \multirow{2}{*}{$\begin{array}{c}\begin{array}{c}\text { Esophageal } \\
\text { sample meanๆ }\end{array} \\
\text { IVDMD }\end{array}$} & \multirow{2}{*}{$\begin{array}{c}\begin{array}{c}\text { Pasture } \\
\text { canopy top\# }\end{array} \\
\text { IVDMD }\end{array}$} & \multirow[t]{2}{*}{$\begin{array}{l}\mathrm{FA} / \mathrm{PCA} \\
\text { ratio+t }\end{array}$} \\
\hline & IVDMD & Yield & & Gain ha ${ }^{-1}$ & $\begin{array}{l}\text { Average } \\
\text { daily gain }\end{array}$ & & & \\
\hline & $\mathrm{g} \mathrm{kg}^{-1}$ & $\mathrm{Mg} \mathrm{ha}^{-1}$ & $\mathrm{~g} \mathrm{~kg}^{-1}$ & $\mathrm{~kg} \mathrm{ha}^{-1} \mathrm{yr}^{-1}$ & $\mathrm{~kg} \mathrm{~d}^{-1}$ & $\mathrm{~g} \mathrm{~kg}^{-1}$ & $\mathrm{~g} \mathrm{~kg}^{-1}$ & \\
\hline NE Trailblazer C-1 & $480 \mathrm{~b} \neq \neq$ & $8.3 \mathrm{a}$ & 490 & 299 & 0.64 & $755 b$ & 660 & $0.78 \mathrm{~b}$ \\
\hline Pathfinder & $494 \mathrm{~b}$ & $8.1 \mathrm{a}$ & 508 & 284 & 0.59 & $759 \mathrm{~b}$ & 673 & $0.82 \mathrm{~b}$ \\
\hline Trailblazer (C1) & $515 a$ & $8.3 \mathrm{a}$ & 504 & 351 & 0.73 & $780 \mathrm{a}$ & 699 & $0.92 \mathrm{a}$ \\
\hline$P \leq$ & 0.05 & 0.05 & NS & 0.05 & 0.05 & 0.10 & NS & 0.01 \\
\hline
\end{tabular}

† Data from Vogel et al. (1981).

₹ Data from Vogel et al. (1984).

$\S$ Data from Anderson et al. (1988).

I Data from Ward et al. (1989). Means are averages of samples collected during the grazing season.

\# Data from Ward et al. (1989). Trailblazer IVDMD was greater than Pathfinder $(P \leq 0.30)$ and NE Trailblazer $C-1(P \leq 0.17)$.

†† FA/PCA = ferulic acid/p-coumaric acid ratio. Data from Gabrielsen et al. (1990).

\# Means followed by the same letter are not significantly different at the 0.05 level of probability except for esophageal samples where the 0.10 level of probability was used; NS indicates the F test was not statistically significant. 
to differential diet selection by the cattle (Ward et al., 1989). The esophageal samples collected from the beef steers were greater in IVDMD than the canopy top samples in IVDMD, but the samples ranked in the same order (Table 1, Ward et al., 1989). These results demonstrated that although beef cattle were selecting higher-quality diets than the available forage, the relative differences among the strains for IVDMD remained the same. The results from the $4 \mathrm{yr}$ of the grazing trials demonstrated that the breeding improvements in IVDMD in switchgrass positively improved both beef cattle gains per hectare and average daily gains. The data from this grazing trial and other similar grazing trials with other species were used by Casler and Vogel (1999) to document that a $10 \mathrm{~g} \mathrm{~kg}^{-1}$ genetic improvement in IVDMD resulted in a $3.2 \%$ increase in beef cattle gains.

Forage digestibility can be genetically altered by changing the cell wall amount as measured by NDF, the amount of crude lignin (ADL), or other cell wall composition factors. Although there were no significant differences among strains in the smallplot trials and the grazing trial for forage composition as measured by the traditional measures of forage quality including NDF, ADF, or ADL, Gabrielsen et al. (1990) demonstrated that averaged over the $3 \mathrm{yr}$, divergent breeding for IVDMD had changed the relative amounts of alkali-labile cell wall phenolics in the forage of the divergently bred strains. Trailblazer (NE Trailblazer C1) had reduced p-coumaric acid (PCA) concentration and a greater PCA/ferulic acid (FA) ratio than NE Trailblazer C-1 (Table 1), and these differences were positively correlated with the differences in IVDMD. Gabrielsen et al. (1990) also demonstrated that the PCA concentration of the forage increased more than $70 \%$ during the grazing season due to increasing maturity of the forage and that these changes were associated with decreases in IVDMD and PCA/FA ratio and increases in NDF, ADF, and ADL. Although the composition of the switchgrass biomass changed as the plants matured, the relative differences in biomass composition variables among the populations remained consistent. These results demonstrated that the divergent breeding for IVDMD had changed the cell wall chemical composition of switchgrass.

\section{Cycle 1, 2, and 3 Sward Evaluation Trials}

After the first three breeding cycles for high IVDMD were completed, a sward trial was established at the Mead site in 1986 to evaluate the breeding progress to date and to obtain estimates of released heritability (Hopkins et al., 1993). The plots were harvested and sampled for biomass yield in 1987 and 1988. The replicated plots were subsampled three times during the growing season each evaluation year by clipping tillers from each plot. The final sampling occurred before biomass harvest, which was when plants in the plots were fully headed. The results of this study demonstrated that IVDMD steadily increased in each breeding cycle but that the Trailblazer $\mathrm{C} 3$ population had significantly lower yields than the $\mathrm{C} 1$ or $\mathrm{C} 2$ strains (Table 2 ). Strain $\times$ sample stage interaction effects were not significant, indicating that the genetic differences in composition remained stable during the growing season (Hopkins et al., 1993). The Trailblazer C-1, C0, C1, and C3 strains were included in a regional switchgrass yield test along with other switchgrass cultivars and experimental strains that was established in 1990 at Mead, Ames, and West Lafayette (Hopkins et al., 1995). The results from this three location study confirmed that the genetic improvements in IVDMD of switchgrass biomass by multiple generations of divergent breeding were consistent and stable across environments (Table 2). The data from this study clearly demonstrated that there was a significant reduction in biomass yield between breeding cycles 1 and 3 .

\section{Winter Survival and Biomass Composition}

As indicated above in the "Breeding History," over 90\% of the plants in the Cycle 4 RRPS selection nursery suffered winter kill during the winter following establishment. The effect of breeding for improved IVDMD on winter survival has been evaluated in three different studies. The first study, which was conducted at three Midwest locations, clearly demonstrated that the NE Trailblazer C3 population had lower mean survival averaged over locations than the NE Trailblazer C-1, NE Trailblazer C0, and Trailblazer over a 3-yr period (Table 3). The decrease in winter survival in each breeding generation for which selection was practiced only for high IVDMD was accompanied by increases in IVDMD and decreases in lignin concentration (Casler et al., 2002). Similar winter survival results were obtained in a separate study at Mead, for the period 1992 through 1995 (Table 3). Winter survival of all the NE Trailblazer populations from C-1 through C5 was evaluated during the period 2006 through 2009. The NE Trailblazer $\mathrm{C} 2$ and NE Trailblazer C3 populations had significantly lower winter survival than the other populations. The NE Trailblazer

Table 2. Forage yield and in vitro dry matter digestibility (IVDMD) of NE Trailblazer germplasms produced by three breeding cycles for high IVDMD and one cycle for low IVDMD in sward trials.

\begin{tabular}{|c|c|c|c|c|c|c|c|c|}
\hline \multirow[t]{2}{*}{ Germplasm } & \multicolumn{2}{|c|}{ Mead ARDC 1987-1988† } & \multicolumn{2}{|c|}{ Mead, NE 1991-1992 means } & \multicolumn{2}{|c|}{ Ames, IA 1991-1992 means } & \multicolumn{2}{|c|}{$\begin{array}{l}\text { West Lafayette, IN 1991-1992 } \\
\text { means } \neq\end{array}$} \\
\hline & Biomass yield & IVDMD & Biomass yield & IVDMD & Biomass yield & IVDMD & Biomass yield & IVDMD \\
\hline & $\mathrm{Mg} \mathrm{ha}^{-1}$ & $\mathrm{~g} \mathrm{~kg}^{-1}$ & $\mathrm{Mg} \mathrm{ha}^{-1}$ & $\mathrm{~g} \mathrm{~kg}^{-1}$ & $\mathrm{Mg} \mathrm{ha}^{-1}$ & $\mathrm{~g} \mathrm{~kg}^{-1}$ & $\mathrm{Mg} \mathrm{ha}^{-1}$ & $\mathrm{~g} \mathrm{~kg}^{-1}$ \\
\hline NE Trailblazer C-1 & 9.6 & 466 & 12.5 & 410 & 10.2 & 417 & 13.0 & 367 \\
\hline NE Trailblazer CO & 8.4 & 481 & 12.3 & 440 & 9.9 & 435 & 11.9 & 406 \\
\hline Trailblazer (C1) & 9.9 & 496 & 12.3 & 444 & 9.8 & 431 & 13.4 & 412 \\
\hline NE Trailblazer C2 & 9.9 & 501 & - & - & - & - & - & - \\
\hline NE Trailblazer C3 & 7.9 & 519 & 10.9 & 491 & 8.5 & 491 & 10.1 & 438 \\
\hline LSD 0.05 & 1.4 & 13 & 0.7 & 11 & 0.8 & 15 & 0.8 & 5 \\
\hline
\end{tabular}

† Data from Hopkins et al. (1993). IVDMD values are means of three sampling times for $2 \mathrm{yr}$. Biomass yields were single cut harvests after plants were headed. ARDC, Agricultural Research and Development Center.

₹ Data from Hopkins (1993), Hopkins et al. (1993), and Hopkins et al. (1995). Biomass yields and biomass samples collected after plants had headed. Four replicates at each location. 
C4 and C5 populations, which were developed by including winter survival as a selection variable, had greater winter survival than the Trailblazer $\mathrm{C} 2$ and $\mathrm{C} 3$ populations (Table 3). They also had reduced IVDMD and increased lignin concentration (Vogel et al., 2013).

In a previous publication, Vogel et al. (2013) reported that these NE Trailblazer populations, in addition to differing significantly for IVDMD and ADL concentrations of the biomass, also differed significantly for NDF, ADF, Klason lignin, N, ash, extracted fat, uronic acids, rhamnose, fucose, arabinose, xylose, mannose, galactose, glucose, p-couramate esters, esterified ferulates, etherified ferulates, sucrose, soluble glucose, fructose, and starch. They, however, did not differ for total C concentration or total cell wall concentration. Selection for IVDMD over generations affected an array of traits affecting the plant cell wall composition. Previous reports have focused on whole tiller composition. Separation of the tillers of plants of NE Trailblazer C-1 through Trailblazer C4 into stem, sheath, and leaf components and analyses of the plant parts show that greater changes were made in the stems than in the leaves (Table 4). Sheath composition results (data not shown) were intermediate between the stem and leaf concentrations. As an example, the difference in ADL concentration between stems for the NE Trailblazer C-1 and NE-Trailblazer $\mathrm{C} 3$ or $\mathrm{C} 4$ was $5 \mathrm{~g} \mathrm{~kg}^{-1}$, whereas for leaves the difference between these populations was $2 \mathrm{~g} \mathrm{~kg}^{-1}$ (Table 4).

\section{Germplasm Uses}

Switchgrass is being developed into a biomass energy crop by research groups being funded by the US Department of Energy, the US Department of Agriculture, and private firms. Modification of its biomass to enhance the production of liquid fuels such as ethanol, syngas, or other biofuels in biorefineries is a primary research objective. These NE Trailblazer populations contain plants that differ genetically for virtually all plant cell wall composition properties. These germplasms can be used in genetics studies for determining the inheritance of multiple biomass composition traits and can be used to identify genes controlling specific biomass composition properties of switchgrass and other perennial grasses that affect forage quality and potential biomass conversion to liquid fuels. The germplasms should also be useful in determining how modifications of plant cell wall composition affect winter survival. To date, these mechanisms are unknown. Since switchgrass and other grasses planted for use as biomass energy crops or forages need to have stand lives of $10 \mathrm{yr}$ or more for economic purposes, the winter survival problem will need to be addressed for all biomass grasses developed with altered cell wall composition.

\section{Seed Availability}

These germplasms were released by USDA-ARS and Agricultural Research Division of the University of Nebraska-Lincoln on 10 Sept. 2014. Seed of these germplasm populations has been deposited in the USDA-ARS National Plant Germplasm System. Two-gram samples will be made available for research purposes from the USDA-ARS Forage and Biomass Project, Lincoln, NE (rob.mitchell@ars.usda.gov), for 5 years from the date of release, after which requests should be made to the USDA-ARS Plant Germplasm System via the Germplasm Resources Information Network (http://www.ars-grin.gov/npgs).

\section{Acknowledgments}

Individuals contributing to the development of the NE Trailblazer C-1 and the cultivar Trailblazer (C1) were K.P. Vogel and H.J. Gorz (USDA-ARS) and F.A. Haskins, University of Nebraska-Lincoln. K.P. Vogel developed the other NE Trailblazer populations and conducted their evaluation. R.B. Mitchell and G. Sarath were involved in the final evaluation of the germplasms. Rumen Fluid for the IVDMD tests was provided by the Animal Science Department of the University of Nebraska-Lincoln over the decades of the breeding and evaluation research. Mention of trade names or commercial products in this publication is solely to provide specific information and does not imply recommendations or endorsement by the US Department of Agriculture. USDA is an equal opportunity employer.

\section{References}

Anderson, B., J.K. Ward, K.P. Vogel, M.G. Ward, H.J. Gorz, and F.A. Haskins. 1988. Forage quality and performance of yearlings grazing switchgrass strains selected for differing digestibility. J. Anim. Sci. 66:2239-2244.

Casler, M.D., D.R. Buxton, and K.P. Vogel. 2002. Genetic modification of lignin concentration affects fitness of perennial herbaceous plants. Theor. Appl. Genet. 104:127-131. doi:10.1007/s001220200015

Casler, M.D., and K.P. Vogel. 1999. Accomplishments and impact from breeding for increased forage nutritional value. Crop Sci. 39:12-20. doi:10.2135/ cropsci1999.0011183X003900010003x

Table 3. Mean survival of NE Trailblazer space-transplanted switchgrass plant populations developed by recurrent selection for increased biomass in vitro dry matter digestibility (IVDMD) in US Midwest environments and IVDMD and acid detergent lignin (ADL) means for the populations from the experiment in which all breeding generations were evaluated. Means were extracted from cited references.

\begin{tabular}{|c|c|c|c|c|c|c|c|}
\hline \multirow[t]{2}{*}{ Germplasm } & \multicolumn{2}{|c|}{$\begin{array}{l}\text { Survival mean average for three } \\
\text { Midwest sites for period 1992-1996+ }\end{array}$} & \multicolumn{2}{|c|}{$\begin{array}{l}\text { Survival means at Mead } \\
\text { for period 1991-1995‡ }\end{array}$} & \multicolumn{3}{|c|}{$\begin{array}{c}\text { Mead for period 2006-2009§ } \\
\text { IVDMD and ADL means for } 2007 \text { and } 2008\end{array}$} \\
\hline & 1993 & 1996 & 2009 & 1995 & Survival 2009 & IVDMD & $A D L$ \\
\hline & $\%$ & $\%$ & $\%$ & $\%$ & $\%$ & $\mathrm{~g} \mathrm{~kg}^{-1}$ & $\mathrm{~g} \mathrm{~kg}^{-1}$ \\
\hline NE Trailblazer C-1 & 90 & 56 & 66 & 68 & 66 & 591 & 53 \\
\hline NE Trailblazer C0 & 89 & 50 & 69 & 76 & 69 & 604 & 49 \\
\hline Trailblazer (C1) & 88 & 48 & 67 & - & 67 & 623 & 48 \\
\hline NE Trailblazer C2 & - & - & 58 & - & 58 & 641 & 44 \\
\hline NE Trailblazer C3 & 84 & 32 & 59 & 54 & 59 & 648 & 44 \\
\hline NE Trailblazer C4 & - & - & 63 & - & 63 & 637 & 45 \\
\hline NE Trailblazer C5 & - & - & 65 & - & 65 & 633 & 47 \\
\hline LSD (0.05) & - & - & 4 & 3 & 4 & 4 & 2 \\
\hline
\end{tabular}

† Data from Casler et al. (2002) and are the means from plots at Mead, NE, Ames, IA, and Arlington, WI. LSD value not available. \# Vogel et al. (2002). Data from entries listed, which were included as check strains in the C4 selection nursery.

$\S$ Data from Vogel et al. (2013). 
Table 4. Composition of stem and leaf tissue of plants of switchgrass populations divergently bred for differences in whole plant in vitro dry matter digestibility (IVDMD). Ten tillers of each plant were harvested after anthesis in 2002, and the tiller sections between the flag leaf and the second collared leaf were hand separated into stem and leaf components. Sample part analysis determined by near infrared spectroscopy.

\begin{tabular}{|c|c|c|c|c|c|c|c|}
\hline Germplasm & IVDMD & NDFt & ADFt & ADL† & $\mathrm{N}+$ & Asht & Lignint \\
\hline & & & & $-\mathrm{gkg}^{-1}$ & & & \\
\hline & & & & Stem & & & \\
\hline NE Trailblazer C-1 & 499 & 734 & 416 & 65 & 4.0 & 6.3 & 58 \\
\hline NE Trailblazer C0 & 496 & 740 & 422 & 63 & 4.2 & 6.6 & 56 \\
\hline Trailblazer & 511 & 731 & 418 & 60 & 4.3 & 6.8 & 53 \\
\hline NE Trailblazer C2 & 509 & 730 & 418 & 60 & 4.6 & 6.8 & 53 \\
\hline NE Trailblazer C3 & 523 & 724 & 413 & 60 & 4.2 & 6.5 & 54 \\
\hline NE Trailblazer C4 & 514 & 731 & 422 & 60 & 4.5 & 7.0 & 53 \\
\hline$F$ test & $23.99 * *$ & $5.38^{* *}$ & $6.03^{* *}$ & $16.98^{* *}$ & $12.45^{* *}$ & $3.65^{* *}$ & $25.34^{* *}$ \\
\hline \multirow[t]{2}{*}{ LSD 0.05} & 2 & 4 & 3 & 1 & 0.1 & 0.2 & 1 \\
\hline & & & & Leaf & & & \\
\hline NE Trailblazer C-1 & 664 & 552 & 271 & 28 & 16.7 & 8.6 & 20 \\
\hline NE Trailblazer C0 & 664 & 548 & 269 & 28 & 16.5 & 8.9 & 20 \\
\hline Trailblazer & 669 & 548 & 269 & 27 & 16.5 & 8.5 & 19 \\
\hline NE Trailblazer C2 & 666 & 546 & 270 & 26 & 16.4 & 8.6 & 18 \\
\hline NE Trailblazer C3 & 667 & 542 & 266 & 26 & 16.4 & 8.7 & 18 \\
\hline NE Trailblazer C4 & 676 & 545 & 266 & 26 & 16.7 & 8.8 & 18 \\
\hline$F$ test & $15.16^{* *}$ & $10.87^{* *}$ & $4.15^{* *}$ & $18.41^{* *}$ & $10.01^{* *}$ & $19.58^{* *}$ & $19.38^{* *}$ \\
\hline $\operatorname{LSD}(0.05)$ & 7 & 4 & 5 & 1 & 0.2 & 0.1 & 1 \\
\hline
\end{tabular}

** Significant at the 0.01 probability level.

+ NDF = neutral detergent fiber; $\mathrm{ADF}=$ acid detergent fiber; $\mathrm{ADL}=$ acid detergent lignin; $\mathrm{N}=$ total nitrogen; $\mathrm{Ash}=$ total ash as determined by combustion; Lignin $=\mathrm{ADL}-$ ash.

Gabrielsen, B.C., K.P. Vogel, B.E. Anderson, and J.K. Ward. 1990. Alkalilabile lignin phenolics and forage quality in three switchgrass strains selected for differing digestibility. Crop Sci. 30:1313-1320. doi:10.2135/ cropsci1990.0011183X003000060032x

Hopkins, A.A. 1993. Genetic variation among switchgrasses for agronomic, forage quality, and biofuel traits. Ph.D. diss., University of Nebraska-Lincoln. ETE Collection for University of Nebraska-Lincoln. Paper AS19322799; http://digitalcommons.unl.edu/dissertations/AAI9322799/.

Hopkins, A.A., K.P. Vogel, and K.J. Moore. 1993. Predicted and realized gains from selection for in vitro dry matter digestibility and forage yield in switchgrass. Crop Sci. 33:253-258. doi:10.2135/cropsci1993.0011183 $\mathrm{X} 003300020007 \mathrm{x}$

Hopkins, A.A., K.P. Vogel, K.J. Moore, K.D. Johnson, and I.T. Carlson. 1995. Genotype effects and genotype by environment interactions for traits of elite switchgrass populations. Crop Sci. 35:125-132. doi:10.2135/cropscil 995.0011183X003500010023x

Newell, L.C. 1968. Registration of Pathfinder switchgrass. Crop Sci. 8:516.

Sarath, G., D. Akin, R.B. Mitchell, and K.P. Vogel. 2008. Cell wall composition and accessibility to enzymes is differentially altered in divergently bred switchgrass (Panicum virgatum. L.) genotypes. Appl. Biochem. Biotechnol. 150:1-14. doi:10.1007/s12010-008-8168-5

Sarath, G., B. Dien, A.J. Saathoff, K.P. Vogel, R.B. Mitchell, and H. Chen. 2011. Ethanol yields and cell wall properties in divergently bred switchgrass genotypes. Bioresour. Technol. 102:9579-9585. doi:10.1016/j. biortech.2011.07.086

Shenk, J.S., and M.O. Westerhaus. 1991. Population definition, sample selection, and calibration procedures for near infrared reflectance spectroscopy. Crop Sci. 31:469-474. doi:10.2135/cropsci1991.0011183X0031000200 $49 \mathrm{x}$
Tilley, J.M.A., and R.A. Terry. 1963. A two-stage technique for in vitro digestion of forage crops. J. Br. Grassl. Soc. 18:104-111. doi:10.1111/j.1365-2494.1963.tb00335.x

Vogel, K.P., R. Britton, H.J. Gorz, and F.A. Haskins. 1984. In vitro and in vivo analyses of hays of switchgrass strains selected for high and low IVDMD. Crop Sci. 24:977-980. doi:10.2135/cropsci1984.0011183X0024000500 $36 \mathrm{x}$

Vogel, K.P., H.J. Gorz, and F.A. Haskins. 1981. Divergent selection for in vitro dry matter digestibility in switchgrass. Crop Sci. 21:39-41. doi:10.2135/ cropsci1981.0011183X002100010011x

Vogel, K.P., F.A. Haskins, H.J. Gorz, B.A. Anderson, and J.K. Ward. 1991 Registration of 'Trailblazer' switchgrass. Crop Sci. 31:1388. doi:10.2135/ cropsci1991.0011183X003100050080x

Vogel, K.P., A.A. Hopkins, K.J. Moore, K.D. Johnson, and I.T. Carlson. 2002. Winter survival in switchgrass populations bred for high IVDMD. Crop Sci. 42:1857-1862. doi:10.2135/cropsci2002.1857

Vogel, K.P., R.M. Mitchell, G. Sarath, H.G. Jung, B.S. Dien, and M.D. Casler. 2013. Switchgrass biomass composition altered by six generations of divergent breeding for digestibility. Crop Sci. 53:853-862. doi:10.2135/cropsci2012.09.0542

Vogel, K.P., and J.F. Pedersen. 1993. Breeding systems for cross-pollinated perennial grasses. Plant Breed. Rev. 11:251-274.

Vogel, K.P., J.F. Pedersen, S.D. Masterson, and J.J. Toy. 1999. Evaluation of a filter bag system for NDF, ADF, and IVDMD forage analysis. Crop Sci. 39:276-279. doi:10.2135/cropsci1999.0011183X003900010042x

Ward, M.G., J.K. Ward, B.E. Anderson, and K.P. Vogel. 1989. Grazing selectivity and in vivo digestibility of switchgrass strains selected for differing digestibility. J. Anim. Sci. 67:1418-1424. 